
Multidisciplinary
SCIENTIFIC JOURNAL
OF MARITIME RESEARCH

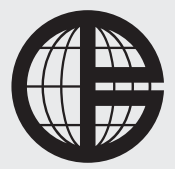
University of Rijeka
FACULTY OF MARITIME STUDIES
Multidisciplinarni
znanstveni časopis
POMORSTVO

\title{
Evaluating Port Operation Managers' Competencies Related to the Port Environmental Sustainability Performance
}

\author{
Özgür Tezcan ${ }^{1}$, Barış Kuleyin² \\ ${ }^{1}$ Çanakkale Onsekiz Mart University, Gelibolu Piri Reis Vocational School, Yazıcızade Mah. Öğretmen Refet Angın Cad., No:13, 17500, Gelibolu, Çanakkale, \\ Turkey, e-mail: ozgurtezcan@comu.edu.tr \\ ${ }^{2}$ Dokuz Eylul University, Maritime Faculty, Adatepe Mah. Doğuș Cad. No: 207/0, 35390, Buca, İzmir, Turkey, e-mail: baris.kuleyin@deu.edu.tr
}

\begin{abstract}
The competency characteristics of managers affect decisions that identifying the strategies in an organization. Similarly, the strategies for sustainability issues are also related to the managers' competency on sustainability. Thus, for better sustainability performance, the managers are expected to possess competencies in this direction. In this context, this study is aimed to evaluate the operations managers' competencies in terms of environmental sustainability in ports, which have huge effects on the physical and biological environment. For this purpose, one of the MultiCriteria Decision Making (MCDM) methods, Analytic Network Process (ANP) was used to evaluate the priority weights of 15 competencies. Within a framework of container ports/terminals, the findings of this study show that "management skill", "emergency procedures", and "safety management" are the most primary competencies of port operations manager (POM) in terms of port environmental sustainability performance (PESP). The model used in this study can contribute to human resourcing and personnel training processes of ports.
\end{abstract}

\section{ARTICLE IN FO}

Review article

Received 22 December 2020

Accepted 1 June 2021

\section{Key words:}

Managerial Competencies

Port Operations Manager

Environmental Sustainability Performance ANP

\section{Introduction}

Ports are places that play an important role in the economic development of a specific region or a country. This role of ports matches being an essential part of international cargo movement and trade. Besides contributing economically, ports also have activities closely related to the social and biological environment (Fossile \& Gouvea Da Costa, 2017). Economical, social, and environmental issues should be handled in a balanced way, which was recognized as the three pillars of sustainability (Markley \& Davis, 2007). "For ports, sustainability means business strategies and activities that meet the current and future needs of the enterprise and its stakeholders, while protecting and sustaining human and natural resources" (AAPA, 2007). Even though maritime transport is one of the most environmental-friendly ones of the current transport modes; considering the magnitude of the activities performed, it is understood that ports must attend importance to sustainability issues (Peris-Mora, Orejas, Subirats,
Ibáñez, \& Alvarez, 2005). As an increasingly developing industry to meet the demands of global trade, ports' activities occur serious concerns about hazardous or noxious substances, greenhouse effect, noise pollution, wastes, and energy consumption. Therefore, the importance attributed to environmental issues in ports are continuously increasing (Sislian, Jaegler, \& Cariou, 2016), and this topic is gradually gain more interest by researchers (Acciaro et al., 2014; Antão et al., 2016; Darbra, Ronza, Stojanovic, Wooldridge, \& Casal, 2005; Puig, Wooldridge, \& Darbra, 2014).

Independently from the size, region and expertise, to perform various activities, ports need to be managed effectively (Burns, 2014). Nowadays, the foremost difficulty that management activities faced in the field of logistics and supply chain is the need for qualified managers (Thai, 2012). Effective management and positive organizational performance require competent managers. For a manager, being competent or as noun form "competency" means "the characteristics that are causally related to effective 
Table 1 POM competencies related to PESP

\begin{tabular}{|c|c|c|c|c|}
\hline Safety management & Decision making & Open-minded & Target-oriented & $\begin{array}{c}\text { Teamwork ability and } \\
\text { management }\end{array}$ \\
\hline Security management & $\begin{array}{c}\text { Regulations / } \\
\text { procedures }\end{array}$ & Analytical thinking & Management skill & $\begin{array}{c}\text { Field knowledge/ } \\
\text { Expertise }\end{array}$ \\
\hline Emergency practices & Problem solving & Action-oriented & $\begin{array}{c}\text { Basic vocational } \\
\text { knowledge }\end{array}$ & Delegating \\
\hline
\end{tabular}

Source: Tezcan and Kuleyin (2019)

and/or superior performance in job" (Boyatzis, 1982: 23). Usually, the organizational structure of a port consists of divisions connected to the Chief Executive Officer (CEO). These divisions are managed by managers like Chief Financial Officer (CFO), Chief Operations Officer (COO), Chief Technical Officer (CTO), etc. (Esmer \& Karataş Çetin, 2016). Each division manager has to have the competency characteristics that are necessary for organizational performance. Organizational performance is vital for meeting the demands of a port's stakeholders. Satisfying stakeholders and reaching a considerable organizational performance requires handling the three dimensions of sustainability simultaneously (Dyllick \& Hockerts, 2002).

Considering the environmental impacts of a port enterprise, the importance of the environmental performance dimension of sustainability stands out. In port management, it is thought that the operations division is the most intertwined one with environmental issues. A COO, generally named as Port Operations Manager (POM), needs engineering information about planning, logistics, transportation, environment, and industry, which are required to manage the port operations that are affecting human health and physical/biological environment. Therefore, this study focused on POM's competencies that are linked to Port's Environmental Sustainability Performance (PESP). This research aims to contribute to manager selection and training activities of a port administration by figuring out linked POM competencies to the PESP. While selecting POMs, focusing on mostly PESP related competencies could contribute to developing environmentally friendly ports. In this context, 15 POM competencies which have determined by a prior study of the authors (Tezcan \& Kuleyin, 2019), were evaluated via Analytical Network Process (ANP).

\section{Literature Review}

\subsection{Competency Studies}

Competency studies in terms of manager characteristics started with Boyatzis's (1982) study. Following this, to identify manager competencies in general, many studies have been made (Chong, 2008; Fang, Chang, \& Chen, 2010; McCredie \& Shackleton, 2000; Quinn, Faerman, Thompson, \& Macgrath, 1990; Viitala, 2005). Some researches searched the relation between managerial competencies and organizational performance (Sanyal \& Guvenli, 2004; Wallick \& Stager, 2002). There are a few studies evaluating manager competencies in the view of organizational sustainability performance or corporate sustainability (Fülöp, 2012; Wesselink, Blok, van Leur, Lans, \& Dentoni, 2015).

There are quite scant researches regarding personnel/ manager competencies in the port sector (Ahn \& McLean, 2008; Thai, 2012; Thai, Yeo, \& Pak, 2016). Lu, Shang, and Lin (2016) carried out a study approaching port sustainability performance from the perspective of port managers. A previous study (Tezcan \& Kuleyin, 2019) of the authors of this study, made an effort to identify the port manager competencies in terms of ports' sustainability performance and reached 15 competency criteria (see Table 1). This study is complementary to that previous study, and it could fill the gap in the literature regarding which competencies really POMs need concerning an environmentally sustainable port.

\subsection{Analytic Network Process (ANP)}

ANP is one of the Multi-Criteria Decision Making (MCDM) methods. The ANP method was proposed by Saaty firstly in 1980, as a developed model for the Analytical Hierarchy Process (AHP). A hierarchical structure cannot be suitable for many decision problems, and the importance of ANP arises at this point (Gencer \& Gürpinar, 2007). To build a model, ANP uses a network instead of hierarchy, and the term "influence" reflects the main perspective of ANP (Saaty, 1999).

Saaty (1999) built the ANP on the AHP, so it has some prominent advantages in general. The main advantage is, because of being a non-linear structure, a flexible network form that permits linking items without hierarchical concerns (see Figure 1). Hence, criteria and clusters of criteria can be in such network structure via inner or outer dependence and feedback (Saaty, 1999).

This kind of network allows prioritizing criteria and clusters of criteria via judging the influence of two criteria on a third criterion with respect to a standard (Saaty, 2004). This judgment process requires numerical pairwise comparisons of dependent criteria. Saaty (2008) proposes a fundamental scale for those judgments (see Table 2).

The Super Decisions (SD) software created by Saaty is the most commonly used analyzing program for ANP stud- 


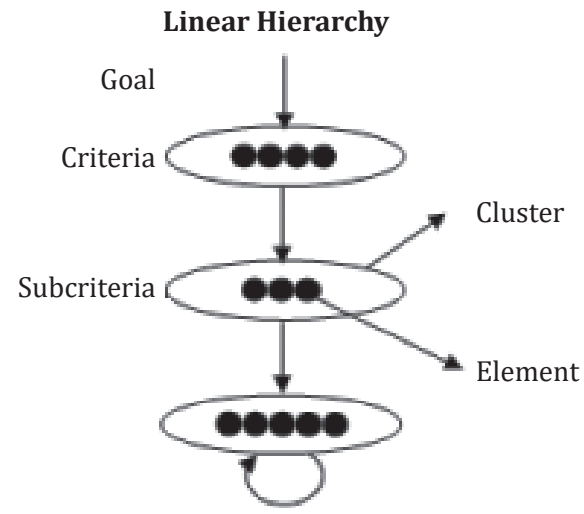

Each element depends only on itself

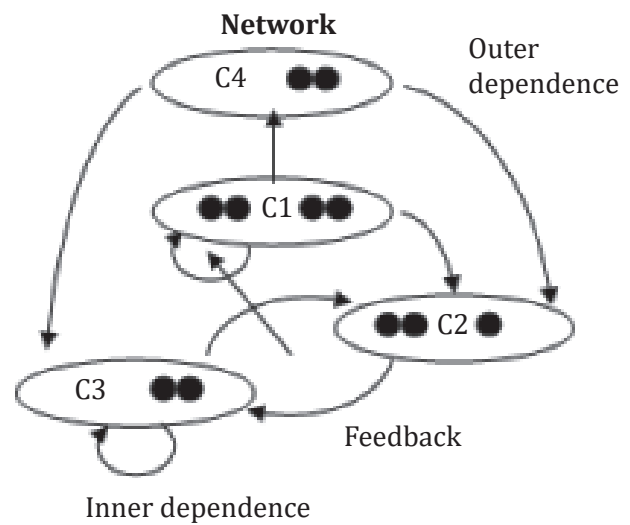

Inner dependence

Figure 1 The Difference of Linear and Nonlinear Network Structure

Source: Saaty and Vargas (2006)

Table 2 Fundamental Scale Used for Pairwise Comparisons

\begin{tabular}{|c|l|}
\hline 1 & Equal importance \\
\hline 3 & Moderate importance of one over another \\
\hline 5 & Strong or essential importance \\
\hline 7 & Very strong or demonstrated importance \\
\hline 9 & Extreme importance \\
\hline $2,4,6,8$ & Intermediate values \\
\hline Use reciprocals for inverse comparisons \\
\hline
\end{tabular}

Source: Saaty (2008)

ies. Ecnet software or mathematical models like Excel and Mathematica can also be used (Gencer \& Gürpinar, 2007).

It is seen from the literature that the ANP method is used increasingly for decision making progresses in various researches. For instance; Niemira and Saaty (2004) used this method for financial crisis forecasting, Cheng and Li (2005) is for project selection, Jharkharia and Shankar (2007) is for logistics service provider selection, Gencer and Gürpinar (2007) is for supplier selection, Yüksel and Dagdeviren (2007) in SWOT analysis, Giannakis, Dubey, Vlachos, and Ju (2020) is for supplier sustainability performance evaluation, etc. ANP method usage in competency studies is scant; Brozova, Subrt, and Vorlickova (2009) used the method for determining a managerial competency model, Alexandra (2015) pursued a competency assessment process for IT professionals, Maaleki and Cyrus (2017) presented a competency model for construction managers.

\section{Methodology and Application}

Considering the complexity of interactions between the competencies evaluated, it was decided that a network structure could be more suitable than a hierarchy, and thus ANP method selected. The Super Decisions 3.2 software was used to analyze the ANP data. While performing this study, below mentioned steps were followed:

\section{Step 1: Determining the decision problem}

This study was planned on prioritizing the POM competencies related to the PESP. To do this, the decision problem is determined as "evaluating the port operations manager competencies in terms of port environmental sustainability performance." The research was conducted within the field of container ports to eliminate the differences that may arise from the type of cargo.

\section{Step 2: Selecting the competencies}

The competencies that were evaluated in this study are those 15 that determined via a Delphi process in a previous study of the authors (Tezcan \& Kuleyin, 2019). These competency criteria were distributed into four clusters according to Viitala's (2005) 'hierarchical model of management competencies' (see Table 3).

Table 3 The POM Competencies Related to the PESP (Clustered)

\begin{tabular}{|c|c|}
\hline Cluster & Competency criterion \\
\hline \multirow{4}{*}{ Technical Competencies } & Emergency practices (T1) \\
\cline { 2 - 2 } & Safety management (T2) \\
\cline { 2 - 2 } & Security management (T3) \\
\cline { 2 - 2 } Business Competencies & Regulations / procedures (T4) \\
\cline { 2 - 2 } Information Management & Field knowledge / expertise (B1) \\
\cline { 2 - 2 } Competencies & Open-minded (B2) \\
\cline { 2 - 2 } & Ananagement skill (B3) \\
\hline \multirow{4}{*}{ Leadership Competencies } & Problem solving (IM2) \\
\cline { 2 - 2 } & Action-oriented (L1) \\
\cline { 2 - 2 } & Target-oriented (L2) \\
\cline { 2 - 2 } & Decision making (L3) \\
\cline { 2 - 2 } & Teamwork ability and \\
\cline { 2 - 2 } & management (L4) \\
\cline { 2 - 2 } & Delegating (L5) \\
\hline
\end{tabular}

Source: Authors 
Step 3: Identifying the relationships and developing the network structure:

ANP is built on a network structure that is independent of a hierarchical frame (Saaty, 1999). This network structure is developed by revealing the relationship between criteria (Saaty, 2008). The relationship between competency criteria and the clusters were evaluated by an influence analysis survey. The survey was prepared to reveal the influence of each competency criterion on others. The survey was applied to three academicians who have expertise in port management. An influence matrix was obtained by the data gathered from the survey. Entering the matrix to the SD software formed the ANP network structure of the research.

\section{Step 4: Performing the pairwise comparisons}

The criteria that are found to be in a relationship together according to the network were compared to each other. The comparisons were questioned the importance level of two criteria relative to each other for another criterion through the 1-9 scale of Saaty (see Table 2), and.
This was performed via a "pairwise comparisons survey" applied to six experts who are in charge of management in executive-level in five different container ports/terminals in Turkey (see Table 4).

There are different ways to reach a common idea about the opinions of the experts related to the pairwise comparisons: (i) consensus, (ii) voting or agreement, (iii) geometric mean, and (iv) separated models (Dyer \& Forman, 1992). In this study, the geometric mean of expert answers was calculated. To make the analysis, this calculated means was coded into the SD software.

\section{Step 5: Analyzing the data}

Analyses start with forming the unweighted supermatrix. This is in a stochastic structure that shows a criterion's influence priority on another criterion in terms of a control criterion (Saaty, 2008). In the second stage, the weighted supermatrix is going to be reached by multiplying the unweighted supermatrix by the priority weights from the clusters (Gencer \& Gürpinar, 2007). The weighted supermatrix shows the priority of criteria in a column

Table 4 The Experts that Performed the Pairwise Comparisons

\begin{tabular}{|c|c|c|c|c|}
\hline Code & Position & Age & $\begin{array}{c}\text { Experience in Maritime Field } \\
\text { (Years) }\end{array}$ & $\begin{array}{c}\text { Experience in Container } \\
\text { Transportation (Years) }\end{array}$ \\
\hline E1 & Chief Executive Officer & 53 & 28 & 19 \\
\hline E2 & Chief Executive Officer & 42 & 19 & 19 \\
\hline E3 & Vice Chief Executive Officer & 52 & 31 & 16 \\
\hline E4 & Chief Operations \& Finance Officer & 47 & 27 & 13 \\
\hline E5 & Chief Operations Officer & 40 & 11 & 5 \\
\hline E6 & Chief Operations Officer & 48 & 22 & 22 \\
\hline
\end{tabular}

Source: Authors

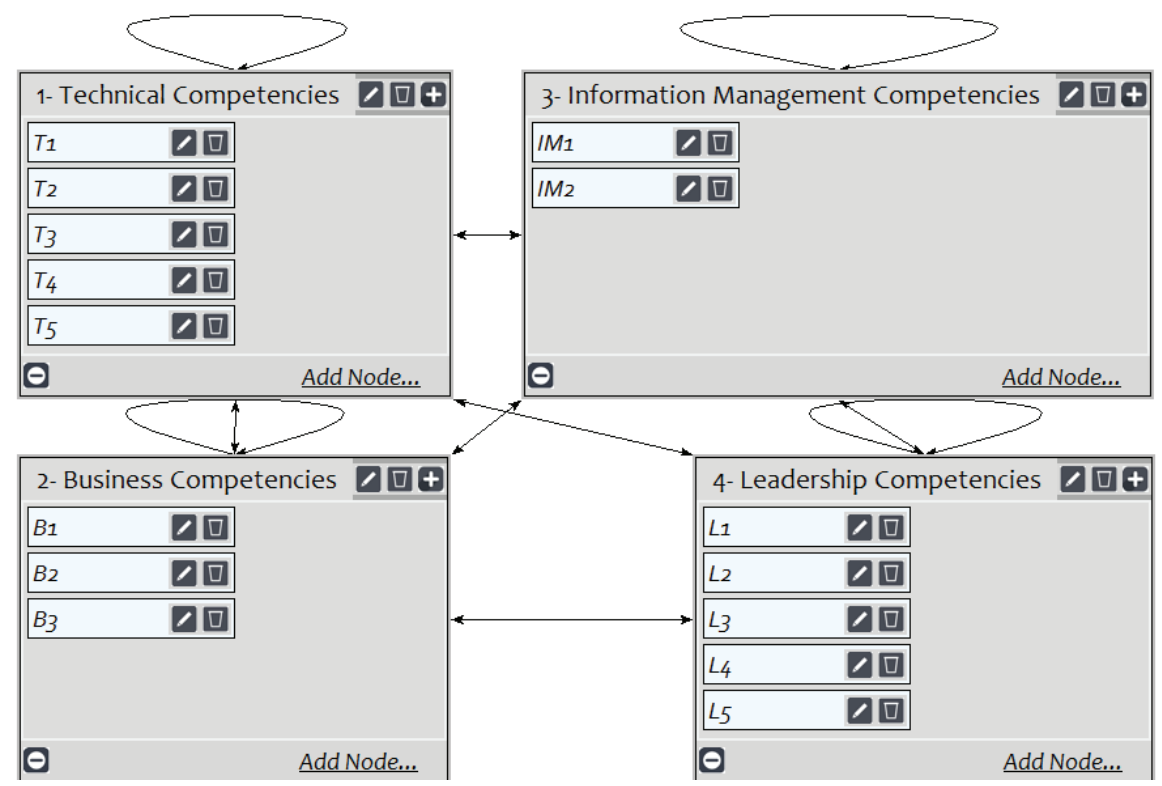

Figure 2 The ANP Model according to the SD 
for each criterion. The sum of each column equals to 1 . The third and the last stage of the analyses is obtaining the limiting supermatrix. To reach the limiting supermatrix, unweighted supermatrix values are raised to limiting powers (Tzeng \& Huang, 2016). SD software calculates unweighted supermatrix, weighted supermatrix and limiting supermatrix values at once.

Consistency is an important concept to be considered in decision problems. While answering pairwise comparisons, the decision-makers have to compare criteria consecutively, and this may cause inconsistency in given answers (Taylor, 2013). For the consistency of research, the consistency ratio is expected to be equal to or less than 0.1 (Saaty, 2008). This ratio is calculated by the SD software for each comparison.

\section{Findings and Discussion}

The answers to the influence analysis survey have been evaluated and the ANP model was formed in SD (see Figure 2). According to the model, all clusters have inner and outer dependence and there is feedback between clusters.

The SD automatically formed the pairwise comparisons according to the model. The experts have evaluated these pairwise comparisons via the pairwise comparisons survey. The geometric mean of each pairwise comparison according to the expert answers were coded to the SD again. Unweighted supermatrix (see Table 5), weighted supermatrix (see Table 6) and limiting matrix (see Table 7) values were calculated. All the consistency ratios of pairwise comparisons were found to be less than 0.1 .

Table 5 Unweighted Supermatrix for Competency Evaluation by using ANP

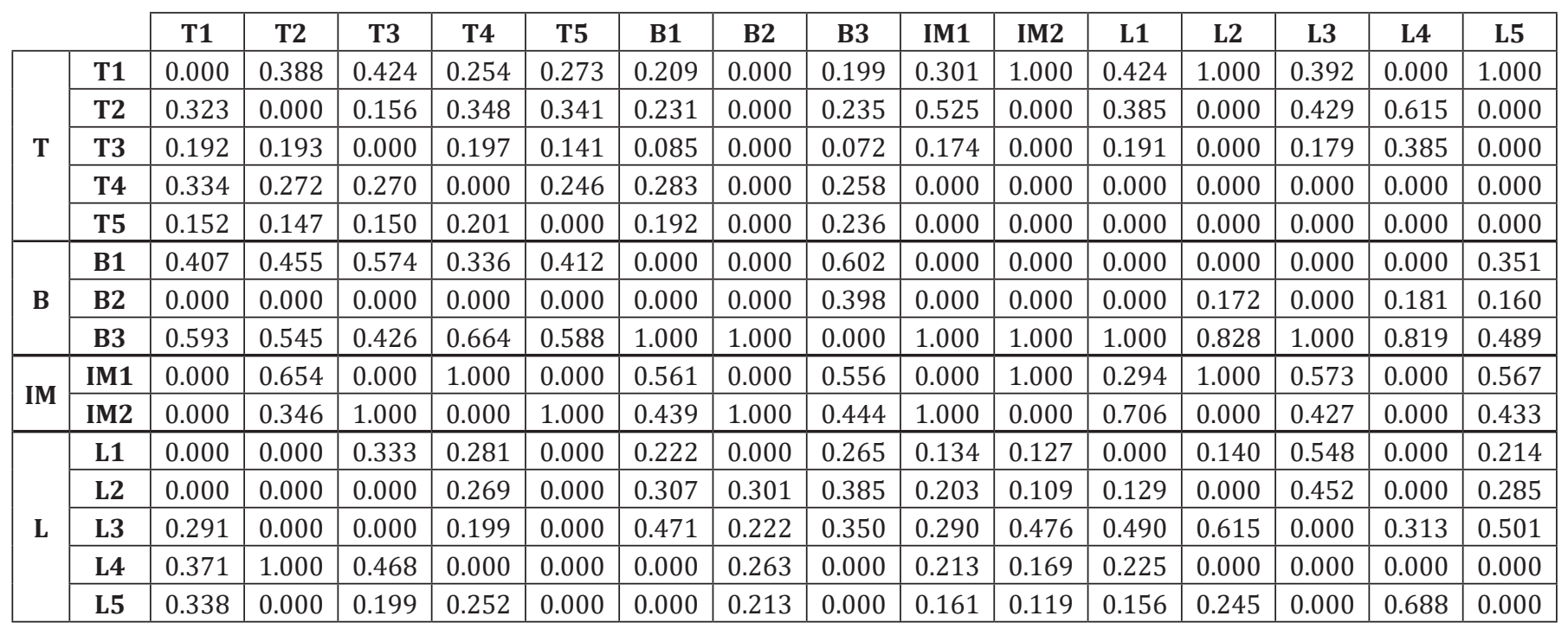

Source: Authors

Table 6 Weighted Supermatrix for Competency Evaluation by using ANP

\begin{tabular}{|c|c|c|c|c|c|c|c|c|c|c|c|c|c|c|c|}
\hline & T1 & T2 & T3 & T4 & T5 & B1 & B2 & B3 & IM1 & IM2 & L1 & L2 & L3 & L4 & L5 \\
\hline T1 & 0.000 & 0.203 & 0.222 & 0.133 & 0.168 & 0.112 & 0.000 & 0.107 & 0.091 & 0.303 & 0.122 & 0.287 & 0.112 & 0.000 & 0.287 \\
\hline T2 & 0.183 & 0.000 & 0.081 & 0.182 & 0.210 & 0.124 & 0.000 & 0.126 & 0.159 & 0.000 & 0.110 & 0.000 & 0.123 & 0.197 & 0.000 \\
\hline T3 & 0.108 & 0.101 & 0.000 & 0.103 & 0.087 & 0.046 & 0.000 & 0.039 & 0.053 & 0.000 & 0.055 & 0.000 & 0.051 & 0.123 & 0.000 \\
\hline T4 & 0.189 & 0.142 & 0.141 & 0.000 & 0.152 & 0.152 & 0.000 & 0.138 & 0.000 & 0.000 & 0.000 & 0.000 & 0.000 & 0.000 & 0.000 \\
\hline T5 & 0.086 & 0.077 & 0.079 & 0.105 & 0.000 & 0.103 & 0.000 & 0.127 & 0.000 & 0.000 & 0.000 & 0.000 & 0.000 & 0.000 & 0.000 \\
\hline B1 & 0.111 & 0.115 & 0.145 & 0.085 & 0.122 & 0.000 & 0.000 & 0.116 & 0.000 & 0.000 & 0.000 & 0.000 & 0.000 & 0.000 & 0.074 \\
\hline B3 & 0.162 & 0.137 & 0.107 & 0.167 & 0.174 & 0.194 & 0.418 & 0.000 & 0.260 & 0.260 & 0.210 & 0.174 & 0.210 & 0.191 & 0.103 \\
\hline IM1 & 0.000 & 0.049 & 0.000 & 0.075 & 0.000 & 0.066 & 0.000 & 0.065 & 0.000 & 0.146 & 0.030 & 0.103 & 0.059 & 0.000 & 0.059 \\
\hline IM2 & 0.000 & 0.026 & 0.075 & 0.000 & 0.088 & 0.051 & 0.253 & 0.052 & 0.146 & 0.000 & 0.073 & 0.000 & 0.044 & 0.000 & 0.045 \\
\hline L1 & 0.000 & 0.000 & 0.050 & 0.042 & 0.000 & 0.034 & 0.000 & 0.040 & 0.039 & 0.037 & 0.000 & 0.056 & 0.219 & 0.000 & 0.085 \\
\hline L2 & 0.000 & 0.000 & 0.000 & 0.040 & 0.000 & 0.047 & 0.099 & 0.059 & 0.059 & 0.032 & 0.052 & 0.000 & 0.181 & 0.000 & 0.114 \\
\hline
\end{tabular}

Source: Authors 
Table 7 Limiting Supermatrix for Competency Evaluation by using ANP

\begin{tabular}{|c|c|c|c|c|c|c|c|c|c|c|c|c|c|c|c|}
\hline & T1 & T2 & T3 & T4 & T5 & B1 & B2 & B3 & IM1 & IM2 & L1 & L2 & L3 & L4 & L5 \\
\hline T1 & 0.133 & 0.133 & 0.133 & 0.133 & 0.133 & 0.133 & 0.133 & 0.133 & 0.133 & 0.133 & 0.133 & 0.133 & 0.133 & 0.133 & 0.133 \\
\hline $\mathrm{T} 2$ & 0.113 & 0.113 & 0.113 & 0.113 & 0.113 & 0.113 & 0.113 & 0.113 & 0.113 & 0.113 & 0.113 & 0.113 & 0.113 & 0.113 & 0.113 \\
\hline T3 & 0.062 & 0.062 & 0.062 & 0.062 & 0.062 & 0.062 & 0.062 & 0.062 & 0.062 & 0.062 & 0.062 & 0.062 & 0.062 & 0.062 & 0.062 \\
\hline T4 & 0.091 & 0.091 & 0.091 & 0.091 & 0.091 & 0.091 & 0.091 & 0.091 & 0.091 & 0.091 & 0.091 & 0.091 & 0.091 & 0.091 & 0.091 \\
\hline T5 & 0.061 & 0.061 & 0.061 & 0.061 & 0.061 & 0.061 & 0.061 & 0.061 & 0.061 & 0.061 & 0.061 & 0.061 & 0.061 & 0.061 & 0.061 \\
\hline B1 & 0.072 & 0.072 & 0.072 & 0.072 & 0.072 & 0.072 & 0.072 & 0.072 & 0.072 & 0.072 & 0.072 & 0.072 & 0.072 & 0.072 & 0.072 \\
\hline B3 & 0.151 & 0.151 & 0.151 & 0.151 & 0.151 & 0.151 & 0.151 & 0.151 & 0.151 & 0.151 & 0.151 & 0.151 & 0.151 & 0.151 & 0.151 \\
\hline IM1 & 0.044 & 0.044 & 0.044 & 0.044 & 0.044 & 0.044 & 0.044 & 0.044 & 0.044 & 0.044 & 0.044 & 0.044 & 0.044 & 0.044 & 0.044 \\
\hline IM2 & 0.042 & 0.042 & 0.042 & 0.042 & 0.042 & 0.042 & 0.042 & 0.042 & 0.042 & 0.042 & 0.042 & 0.042 & 0.042 & 0.042 & 0.042 \\
\hline L1 & 0.038 & 0.038 & 0.038 & 0.038 & 0.038 & 0.038 & 0.038 & 0.038 & 0.038 & 0.038 & 0.038 & 0.038 & 0.038 & 0.038 & 0.038 \\
\hline L2 & 0.039 & 0.039 & 0.039 & 0.039 & 0.039 & 0.039 & 0.039 & 0.039 & 0.039 & 0.039 & 0.039 & 0.039 & 0.039 & 0.039 & 0.039 \\
\hline
\end{tabular}

Source: Authors

The unweighted supermatrix indicates the cluster priority weights for each criterion. The sum of the priority weights about a criterion in a cluster equals 1 . The values shown as ' 0.000 ' means that there is no relationship between intersecting criteria.

The weighted supermatrix indicates priority weights in a criteria-based way. Each column represents a criterion and the sum of a column is equals to 1 . To point some high values, e.g.; the $B 3$ (management skill) criterion is extremely prior (0.418) for the B2 (open-minded) criterion, $L 5$ (delegating) criterion is highly prior $(0.307)$ for the $L 4$ (teamwork ability and management) criterion, T1 (emergency procedures) criterion is highly prior $(0.303)$ for the IM2 (problem-solving) criterion.

The limiting supermatrix reveals the priority weights of POM competencies in terms of PESP. According to this, the priority rankings of competency criteria and cluster rankings are given in Table 8-9.

The most prior POM competency in terms of PESP has been found to be the 'management skill (B2)' (0.151). 'Management skill' competency has been discussed in many competency studies (Ahn \& McLean, 2008; Fang et al., 2010; Shang \& Yu, 2013; Thai, 2012). Fang et al. (2010), found the 'management skill' as fourth prior competency in their study in relation to the healthcare managers. Considering prior studies and the findings of this study, it can be said that the management skill competency is more important for port management. Besides, the competencies 'emergency procedures (T1)' (0.133) and 'safety management (T2)' (0.113) placed second and third rankings in priority weight. These competencies differentiate port management from the other management fields. Finding high priority in terms of PESP of these two competencies, which include prevention and intervention methods for incidents against the environment, is considered significant.
Table 8 Priority Weight Rankings of POM Competencies in terms of PESP

\begin{tabular}{|c|c|c|}
\hline Code & Competency Criterion & Weight \\
\hline B3 & Management skill & 0.151 \\
\hline T1 & Emergency procedures & 0.133 \\
\hline T2 & Safety management & 0.113 \\
\hline T4 & Regulations / procedures & 0.091 \\
\hline B1 & Field knowledge / expertise & 0.072 \\
\hline L3 & Decision making & 0.062 \\
\hline T3 & Security management & 0.062 \\
\hline T5 & Basic vocational knowledge & 0.061 \\
\hline IM1 & Analytical thinking & 0.044 \\
\hline IM2 & Problem solving & 0.042 \\
\hline L4 & Teamwork ability and management & 0.039 \\
\hline L2 & Target-oriented & 0.039 \\
\hline L1 & Action-oriented & 0.038 \\
\hline L5 & Delegating & 0.035 \\
\hline B2 & Open-minded & 0.016 \\
\hline & & 1.000 \\
\hline
\end{tabular}

Source: Authors

When focusing on the clusters, it is seen that the technical competencies found to be highly prior, and the priority of leadership competencies found to be lower relatively. This indicates the professional knowledge and ability are more important than having strong leadership characteristics in port management.

On cluster basis, the 'management skill' competency differentiates from other competencies in business competencies cluster. This can be said also for 'decision making' competency in leadership competencies cluster. The priority weights in the other two clusters are found to be relatively close together. The average priority weights of 
Table 9 Priority Weight Rankings of Competency Clusters

\begin{tabular}{|c|c|c|c|}
\hline Cluster & Code & Competency Criterion & Weight \\
\hline \multirow{5}{*}{ Technical Competencies } & $\mathrm{T} 1$ & Emergency procedures & 0.288 \\
\hline & $\mathrm{T} 2$ & Safety management & 0.246 \\
\hline & T3 & Security management & 0.135 \\
\hline & T5 & Basic vocational knowledge & 0.112 \\
\hline & & & 1.000 \\
\hline \multirow{3}{*}{ Business Competencies } & B1 & Field knowledge / expertise & 0.300 \\
\hline & B2 & Open-minded & 0.067 \\
\hline & & & 1.000 \\
\hline \multirow[b]{2}{*}{ Information Management Competencies } & IM1 & Analytical thinking & 0.518 \\
\hline & IM2 & Problem solving & 0.482 \\
\hline \multirow{4}{*}{ Leadership Competencies } & L1 & Action-oriented & 0.179 \\
\hline & $\mathrm{L} 2$ & Target-oriented & 0.178 \\
\hline & L5 & Delegating & 0.166 \\
\hline & & & 1.000 \\
\hline
\end{tabular}

Source: Authors

criteria in clusters are respectively as follows; technical 0.092 , business 0.080 , information management 0.043 , and leadership 0.042 . This ranking is exactly fit with the ranking in Viitala's (2005) model.

\section{Conclusions}

Ports are places that contain activities of intensive vehicle and ship traffic, and equipment usage. These activities cause significant energy consumption, and a considerable amount of wastes in solid, liquid and gas form. This reality forces port enterprises to consider environmental sustainability issues. Port enterprises have to push up environmental sustainability performance for the sustainability of the ecosystem, protecting the positive interaction with the social environment, sustaining economically, and corporate reputation.

The port activities that have environmental effects are mostly the responsibility of a POM. Thus, POM's are at the focal point of PESP. In this respect, POM's are expected to have competencies supporting PESP. In this study, it is aimed to determine the priority weights of POM competencies in terms of PESP. For this purpose, one of the MCDM methods, the ANP has been used.

As one of the pioneer studies evaluating manager competencies in the maritime field by an MCDM method, this paper shows that the managerial skill of a POM is vital for the PESP. This competency has also been found to be important in studies addressed ports or other management fields. This makes it a priority to have experience in lower management levels when hiring a POM, so port enter- prises should take this into account. Additionally, technical and port-related competencies like emergency practices, safety management, etc. stand out. It indicates that a POM needs different specific competencies than the managers of other business fields have. This means the POMs should have had enough education in maritime training schools to gain those technical competencies and have enough field experience to intensify their knowledge with practical implementations. Considering the environmental sustainability performance of a port, and overall sustainability, these competencies should be taken into account while hiring a POM. POMs presently in charge could be developed via these competencies via in-service training.

A questionnaire that explores the priority competencies pointed out by the findings of this study could be created, and applied during a job interview. This can help select and hire the right POM for an environmentally sustainable port operation. Further studies investigating manager competencies in the maritime field from different perspectives could be useful. Competencies of managers in ports handling other types of cargoes or, competencies of different levels of managers could be analyzed.

Funding: The research presented in the manuscript did not receive any external funding.

Acknowledgement: This article is derived from Özgür Tezcan's PhD dissertation entitled "Evaluating Port Managers' Primary Competencies in Terms of Port's Sustainability Performance", conducted under the supervision of Barış Kuleyin. 
Author Contributions: Conceptualization: Özgür Tezcan and Barış Kuleyin, Methodology: Özgür Tezcan and Barış Kuleyin, Data collection: Özgür Tezcan, Research: Özgür Tezcan and Barış Kuleyin, Writing: Özgür Tezcan, Review and editing: Barış Kuleyin,

\section{References}

[1] AAPA. (2007). American Association of Port Authorities. Embracing the Concept of Sustainabilty as a Standard Business Practice for Ports and the Association. Retrieved from http://aapa.files.cms-plus.com/PDFs/sustainability_resolutions.pdf.

[2] Acciaro, M., Vanelslander, T., Sys, C., Ferrari, C., Roumboutsos, A., Giuliano, G., Kapros, S. (2014). Environmental sustainability in seaports: a framework for successful innovation. Maritime Policy \& Management, 41(5), 480500.

[3] Ahn, Y.-s., \& McLean, G. N. (2008). Competencies for port and logistics personnel: An application of regional human resource development. Asia Pacific Education Review, 9(4), 542-551.

[4] Alexandra, T. E. (2015). Application of the Analytic Network Process to competency Assessment Process of IT Professionals. Ovidius University Annals, Series Economic Sciences, 15(1).

[5] Antão, P., Calderón, M., Puig, M., Michail, A., Wooldridge, C., \& Darbra, R. (2016). Identification of occupational health, safety, security (OHSS) and environmental performance indicators in port areas. Safety science, 85, 266-275.

[6] Boyatzis, R. E. (1982). The competent manager: A model for effective performance: John Wiley \& Sons.

[7] Brozova, H., Subrt, T., \& Vorlickova, L. (2009). The system approach to knowledge creation, sharing and utilisation in managerial competency models. International Journal of Learning and Intellectual Capital, 6(1-2), 103-116.

[8] Burns, M. G. (2014). Port management and operations: CRC press.

[9] Cheng, E. W., \& Li, H. (2005). Analytic network process applied to project selection. Journal of construction engineering and management, 131(4), 459-466.

[10] Chong, E. (2008). Managerial competency appraisal: A cross-cultural study of American and East Asian managers. Journal of Business Research, 61(3), 191-200.

[11] Darbra, R., Ronza, A., Stojanovic, T. A., Wooldridge, C., \& Casal, J. (2005). A procedure for identifying significant environmental aspects in sea ports. Marine pollution bulletin, 50(8), 866-874.

[12] Dyer, R. F., \& Forman, E. H. (1992). Group decision support with the analytic hierarchy process. Decision support systems, 8(2), 99-124.

[13] Dyllick, T., \& Hockerts, K. (2002). Beyond the business case for corporate sustainability. Business strategy and the environment, 11(2), 130-141.

[14] Esmer, S., \& Karataş Çetin, Ç. (2016). Liman İşletme Yönetimi. In Denizcilik Isşletmeleri Yönetimi (pp. 379-415). İstanbul: Beta.

[15] Fang, C.-H., Chang, S.-T., \& Chen, G.-L. (2010). Competency development among Taiwanese healthcare middle manager: A test of the AHP approach. African journal of business management, 4(13), 2845-2855.
[16] Fossile, D. K., \& Gouvea Da Costa, S. E. (2017). Sustainable Management in Ports. Paper presented at the 6th International Workshop Advances in Cleaner Production, Sao Paulo.

[17] Fülöp, G. (2012). Corporate Sustainability and Managerial Competencies. Theory, Methodology, Practice, 8(2), 17.

[18] Gencer, C., \& Gürpinar, D. (2007). Analytic network process in supplier selection: A case study in an electronic firm. Applied mathematical modelling, 31(11), 2475-2486.

[19] Giannakis, M., Dubey, R., Vlachos, I., \& Ju, Y. (2020). Supplier sustainability performance evaluation using the analytic network process. Journal of Cleaner Production, 247, 119439.

[20] Jharkharia, S., \& Shankar, R. (2007). Selection of logistics service provider: An analytic network process (ANP) approach. Omega, 35(3), 274-289.

[21] Lu, C.-S., Shang, K.-C., \& Lin, C.-C. (2016). Examining sustainability performance at ports: port managers' perspectives on developing sustainable supply chains. Maritime Policy \& Management, 43(8), 909-927.

[22] Maaleki, A., \& Cyrus, K. M. (2017). Project manager competency model based on ANP method in construction projects. Paper presented at the 7th International Conference on Industrial Engineering and Operations Management.

[23] Markley, M. J., \& Davis, L. (2007). Exploring future competitive advantage through sustainable supply chains. International Journal of Physical Distribution \& Logistics Management.

[24] McCredie, H., \& Shackleton, V. (2000). The unit general manager: a competency profile. Personnel Review, 29(1), 106114.

[25] Niemira, M. P., \& Saaty, T. L. (2004). An analytic network process model for financial-crisis forecasting. International journal of forecasting, 20(4), 573-587.

[26] Peris-Mora, E., Orejas, J. D., Subirats, A., Ibáñez, S., \& Alvarez, P. (2005). Development of a system of indicators for sustainable port management. Marine Pollution Bulletin, 50(12), 1649-1660.

[27] Puig, M., Wooldridge, C., \& Darbra, R. M. (2014). Identification and selection of environmental performance indicators for sustainable port development. Marine pollution bulletin, 81(1), 124-130.

[28] Quinn, R. E., Faerman, S. R., Thompson, M. P., \& Macgrath, M. (1990). Becoming a master manager. New York: Wiley \& Sons.

[29] Saaty, T. L. (1999). Fundamentals of the analytic network process. Paper presented at the Proceedings of the 5th international symposium on the analytic hierarchy process.

[30] Saaty, T. L. (2004). Fundamentals of the analytic network process-Dependence and feedback in decision-making with a single network. Journal of Systems science and Systems engineering, 13(2), 129-157.

[31] Saaty, T. L. (2008). The Analytic Network Process. Iranian Journal of Operational Research, 1(1), 1-27.

[32] Saaty, T. L., \& Vargas, L. G. (2006). Decision making with the analytic network process (Vol. 282): Springer.

[33] Sanyal, R. N., \& Guvenli, T. (2004). Perception of managerial characteristics and organizational performance: comparative evidence from Israel, Slovenia, and the USA. Cross Cultural Management: An International Journal, 11(2), 35-57.

[34] Shang, H., \& Yu, W. (2013). Assessing Chinese managerial competencies from different perspectives. Social Behavior and Personality: an international journal, 41(9), 1469-1485. 
[35] Sislian, L., Jaegler, A., \& Cariou, P. (2016). A literature review on port sustainability and ocean's carrier network problem. Research in Transportation Business \& Management, 19, 19-26.

[36] Taylor, B. W. (2013). Introduction to Management Science (11 ed.): Pearson.

[37] Tezcan, Ö., \& Kuleyin, B. (2019). Academicians Viewpoint on Port Managers Prior Competencies in terms of Environmental Sustainability Performance of Container Port Enterprises in Turkey. Journal of ETA Maritime Science, 7(4), 280-292.

[38] Thai, V. V. (2012). Competencies required by port personnel in the new era: conceptual framework and case study. International Journal of Shipping and Transport Logistics, 4(1), 49-77.

[39] Thai, V. V., Yeo, G.-T., \& Pak, J.-Y. (2016). Comparative analysis of port competency requirements in Vietnam and Korea. Maritime Policy \& Management, 43(5), 614-629.

[40] Tzeng, G.-H., \& Huang, J.-J. (2016). Multi Attribute Decision Making: Methods and Applications. USA, CRC Press. Wu, K.,
Zhao, N., Gao, L., Lee, CKM (2016). Production control policy for tandem workstations with constant service times and queue time constraints, International Journal of Production Research. Published online, 5, 8-15.

[41] Viitala, R. (2005). Perceived development needs of managers compared to an integrated management competency model. Journal of Workplace Learning, 17(7), 436-451.

[42] Wallick, W. G., \& Stager, K. J. (2002). Healthcare managers' roles, competencies, and outputs in organizational performance improvement/Practitioner response. Journal of Healthcare Management, 47(6), 390.

[43] Wesselink, R., Blok, V., van Leur, S., Lans, T., \& Dentoni, D. (2015). Individual competencies for managers engaged in corporate sustainable management practices. Journal of Cleaner Production, 106, 497-506.

[44] Yüksel, İ., \& Dagdeviren, M. (2007). Using the analytic network process (ANP) in a SWOT analysis-A case study for a textile firm. Information sciences, 177(16), 3364-3382. 